INTERNATIONAL JOURNAL OF RESEARCH IN SOCIAL SCIENCES \& HUMANITIES

An International Open-Access Peer Reviewed Referred Journal

New Instutictitions

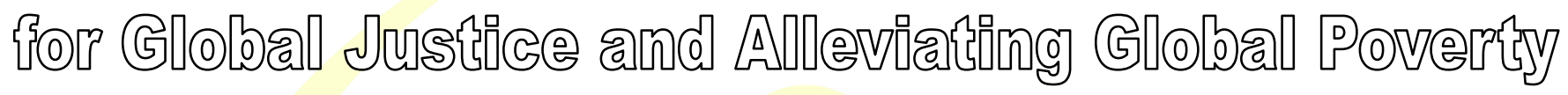

\title{
Santosh Kumar
}

Research Scholar, Department of Political Science, University of Delhi DOI: http://doi.org/10.37648/ijrssh.v11i03.017
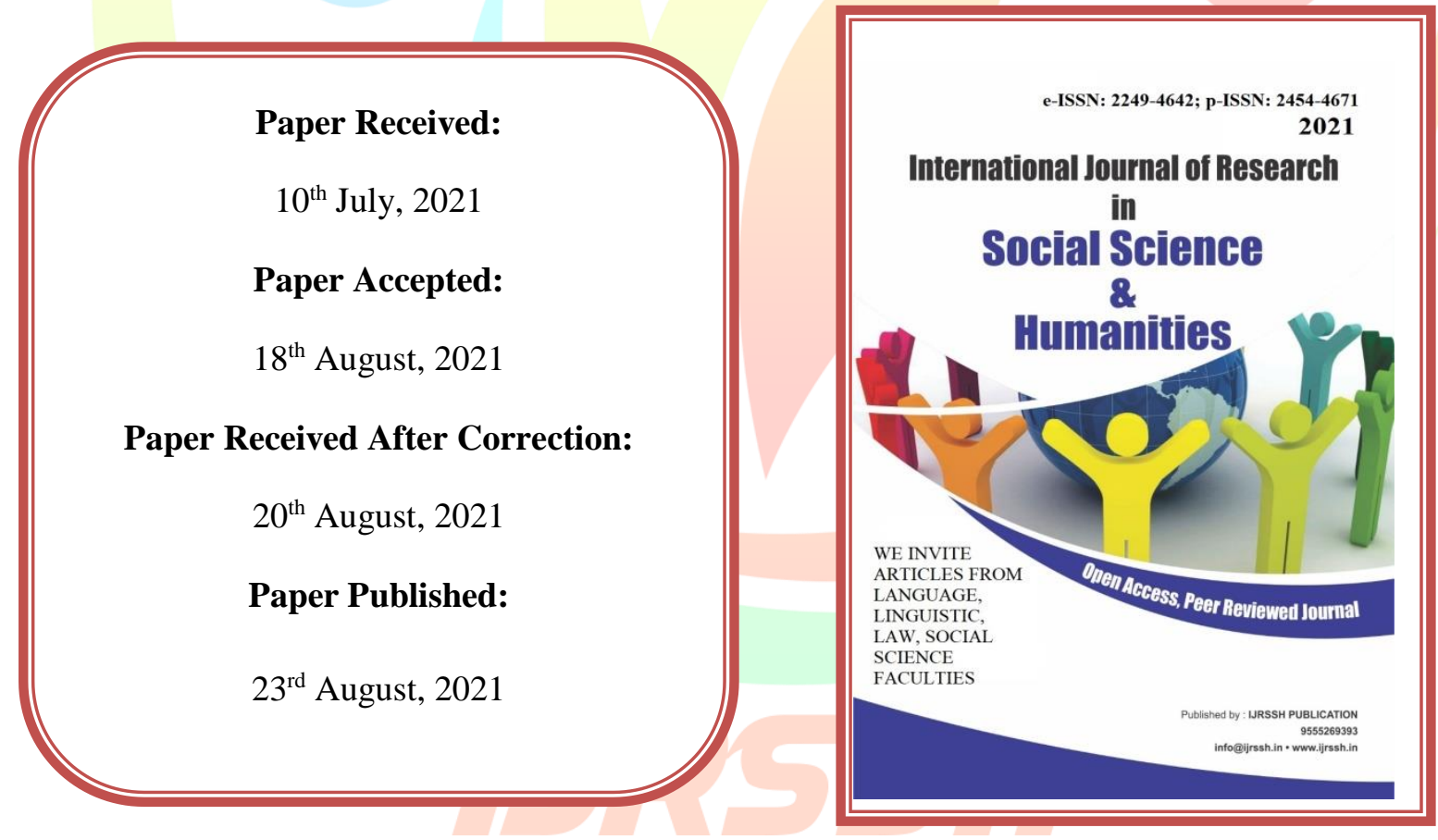

How to cite the article: Santosh Kumar, New Institutions for Global Justice and Alleviating Global Poverty, July-September 2021 Vol 11, Issue 3; 293-303 DOI: http://doi.org/10.37648/ijrssh.v11i03.017 


\title{
Volume: 11, Issue: 3, July-September 2021
}

\begin{abstract}
Alleviation of global poverty, especially in the global South has an urgent issue of moral concern for world leadership. Global institutions have laid down various proposals to eradicate poverty across the globe but nothing substantial has changed and still millions of people are living in acute poverty. Global academia especially political theorists/philosophers have tried to address the issue of global poverty and in this paper I will be discussing the cosmopolitan position to address the issue. The proposed paper seeks to explore: what must a globally egalitarianinstitutional design look like that addresses the morally urgent problem of global poverty,especially in the global south?
\end{abstract}




\section{Volume: 11, Issue: 3, July-September 2021}

Various global justice theorists and philosophers have offered proposals for protecting the basic human rights of the global poor but they are primarily concerned with reforms in the existing global order rather than designing it from the perspective of the global south. Thomas Pogge's Global Resources Dividend (GRD) is a compensatory model which aims at rectifying the historical injustice and does not come up with any feasible institutional design to alleviate poverty in the global south. Martha Nussbaum discusses ten principles and includes domestic basic structure, international institutions, business groups, and NGOs into the global structure but she is not clear what institutional arrangement is required to globalize the capabilities ensuring minimum decent life of the global poor. Simon Caney's proposal of liberalegalitarian governance does not deal with the issues of non-compliance, bad brute luck, and the necessity of immediacy required for addressing the issues of poverty in the global south. Allen Buchanan's cosmopolitan institutional proposal based on the preventive use of force faces certain limitations: firstly, the authorization of the preventive use of force" by the United Nations Security Council (UNSC) to protect the basic human rights of the global poor undermines the fairness and decision making autonomy of the body; secondly, since the global south has no fair representation in the UNSC the authorization may also go against its own interests; thirdly, the structure may collapse as it can divide the states into those who support the preventive use of force and those who do not.

The proposed institutional design is perhaps a model involving the vertical dispersal of sovereignty which is better understood as a shared and multilayered structure. The layers will function within the framework of cooperative relationship based on mutual moral responsibility. The design assumes to posses some properties for its effectiveness such as global deliberative equality to ensure the voice and representation of the global south, decentralized decision- making, sovereign equality, shared vision and ownership, mutual reciprocity,

An exploration of this may well require methodologically an interdisciplinary framework thatcan successfully integrate both the normative and empirical approaches in order to work out what is politically feasible. This will involve (a) mapping out the comparative strengths of existing proposal to reform or redesign the global order, (b) comparing the frameworks of global distributive justice, 


\section{Volume: 11, Issue: 3, July-September 2021}

and (b) a normative interrogation of the existing performance of global institutions and the proposed design. For its normative analysis it will derive some of the insights from philosophicalanthropology, political philosophy, moral psychology, political economy and international relations.

In this interdependent world, as far as global poverty is concerned, the issues of global institutional design have been the central focus for both the policy makers and global justice theorists. The existing supranational institutions have significantly failed and globalization has miscarried its goal in mitigating poverty in the Global South. We were led to believe in the last couple of decades that with increasing globalization the gap between the rich and the poor would be significantly reduced. But nothing of the sort has happened and on the contrary this gap, many analysts claim, has increased. Our moral concern regarding global poverty is compounded by yet another factor: powerful global actors and agencies have all but abdicated or significantly reduced the responsibility of alleviating the conditions of the global poor. In the meantime, however, studies in global justice across the humanities and social sciences have gained momentum. Much of the philosophical literature on global justice that usually, though not exclusively, begin with the problem of global poverty stake out a wider domain of moral responsibility that is truly global in character. Any understanding of this moral responsibility, it is argued, is intimately linked with the ethics and politics of redistribution. And beyond this, scholars also debate-more in disagreement than in agreement-on how to work through the existing institutions in order to transform the moral responsibility to a set of feasible political goals.

A set of interrelated questions beg our attention: how do we explain what poverty is and what counts as minimal well-being? Are only states responsible for alleviating poverty through policies of domestic redistribution? Or, are states, in spite of their limited autonomy, also affected by forces not within their control?

Some global justice theorists fault the global institutions for violating the human rights of the global poor, usually ways in which they inflict harms upon them, both direct and indirect. On this view, poverty as a condition caused by a denial of rights, may also be seen as a state of powerlessness where the poor are unable to fulfil their basic needs necessary for leading decent lives, as well as a failure on the part of the 


\section{Volume: 11, Issue: 3, July-September 2021}

transnational institutions toward creating adequate opportunities that allow the global poor fair access to resources required for their basic needs and survival. The proposed research argues that any global commitment to the respect for human rights must have egalitarian implications for the global institutions which may, in turn, require appropriate redesign.

Some global justice such as Thomas Pogge, Simon Caney, Pablo Gilabert differ on the scope, effectiveness, and nature of the duty of justice. Supporting an interactional understanding of human rights Pablo and Caney criticize Pogge's (2005) negative duty of justice which is based on the harm principle and the necessity of institutional membership in order to help others living beyond the national borders. Caney further argues that even if the well-off people of the developed nations claim that they do not interact with the worst-off on the everyday basis that causes harm but it does not limit their duty of justice to the national borders because in this interdependent world, the global poor are mediated and affected by the various policies of global institutions to which they are parties of.

Caney Criticizes nationalists such as

David Miller, John Rawls, Thomas
Nagel etc. for being principally and pragmatically sceptical to extend globally the domestic domain of the distributionof benefits and resources. $\mathrm{He}$ attracts scholarly attention on a different set of related questions: why should nations give up their ownership rights over the natural resources that are within their own territory? And what moral obligations do states owe towards the resource deficient states in order to eradicate global poverty and fulfil the rights of the global poor?

Charles Beitz (1979, 2005) suggests an important design for the global distribution of natural resources but does not answer why world leaders who are the party to the contract choose for distribution of natural resources only and not the benefits that accrue from unequal ownership. Martha Nussbaum (2004), criticizing the social contractarian tradition, proposes the idea of human development approach' as a suitable alternative to eradicate global poverty that enhances the basic human capabilities of the global poor to lead decent lives. Pogge's (2001, 2005, 2011) makes a breakthrough with the proposal the Global Resources Dividend (GRD) arguing that the well-off have to pay back the worst-off for massive consumption of the global resources from which they have been excluded. But it does not 


\section{Volume: 11, Issue: 3, July-September 2021}

clearly reflect what institutional structurewhether coercive, semi-coercive, decentralized, or shared is required to enforce the developed nations in order to follow their moral obligation of helping the global poor through the commonlypooled fund. Considering GRD as a feasible reference point, the proposed research makes an attempt to theorize upon egalitarian principle(s) of distribution and tries to visualize that what type of institutional structure is needed to actualize them under non-ideal circumstances.

As far as principles of global distribution and institutional structure are concerned, Global justice theorist Simon Caney (2001, 2005, 2008) has explored these questions and has theorized at length to address the problems of global poverty. He criticises nationalists such as Michael Blake (2002) and Thomas Nagel (2005) for emphasising too much on the normative significance of the state and for arguing that egalitarian principles of equality is applicable only at the domesticlevel because it has a system of political coercion. He says that they have failed to understand thedirect and indirect coercion and its moral significance for global redistribution. Caney (2006) also criticizes Mathias Risse (2005) for not explaining why distributive justice should be a function of legal and political immediacy and what significance it carries at the global level. He admits that immediacy' is necessary but it is vague to argue for political and legal immediacy as prerequisite of the distributive justice. He further argues that it will be too early to argue for what level of immediacy' is required to arrive upon demanding principle(s) of redistribution at the global level?

Caney (2006) probes into the existing approaches for global institutions design in a detailed manner. Distinguishing between the =wholly democratic approach,' on the one hand, and the =wholly instrumental approach,' on the other, for institutional design and rejecting both of them as equally implausible, he favours a mixed approach.' Following the _mixed approach" he argues that a system of international institutions should posses some properties such as equalization of influence, facilitation of the participation of the vulnerable, ensuring of effective enforcement mechanisms that are equally available to all, provision of an international ombudsman, peer accountability, transparency, public justifiability, and democratic accountability. But there are certain interrelated questions that require our attention and need to be re-engaged with. They are: 


\section{Volume: 11, Issue: 3, July-September 2021}

(a) What will be the nature

and level of ",immediacy" in order to work out any principle(s) of global distribution? How must this address the issues of „bad brute luck"?

(b) What mechanisms of decentralization may be required to uphold states" autonomy and still enable and make them accountable to global duties of justice?

\section{The Proposed Institutional Design}

Layer I - it will be a deliberative body of the world leaders with special focus on the representation from the Global South. This body will deliberate upon the issues of setting up a global fund and other related issues of financing, directly or indirectly poverty alleviation programmes in the global south. It aims at enforcing the duty of justice down the layers.

Layer II--Global Institutions (the World Bank, the WTO, the IMF, \& others)--they will be expected to function as an egalitarian institutions to ensure fair distribution of benefits and resources at the global level.

Layer III--Business Corporations (MNCs, TNCs, \& others) - they should mobilize the resources wherever they do business and help the local government in ensuring the minimum decent survival for the global poor.

Layer IV--Global Civil Society, NGOs \& Social Movements - they will act as an _anti- systemic $^{1}$ agencies to draw the attention of all the above three layers regarding their duty of justice in mitigating poverty in the global south. For examples, at present, they can remind global institutions and world leaders of their promises to achieve Millennium Development Goals (MDGs) by 2015.

I believe that the allocation of duty of justice is an ethical task and it does not necessarily require coercion all the time. But to fulfil these kinds of responsibilities, the top layer of the proposed design must be equipped with legal and political immediacy ${ }^{2}$ to deal with the non-complier actors \& enforcing the duty of justice down the layers. I further argue that in such an interdependent world, the realization of basic moral rights cannot be domestic

\footnotetext{
${ }^{1}$ The term is taken from Immanuel Wallerstein's article, -New Revolts Against the Systemll, New Left Review, Vol.18, 2002

${ }^{2}$ But my approach to immediacy ${ }^{6}$ differs from nationalists' idea that it is/should be limited by national borders considering state as the only juridical body to implement it. Rather I wish to explore what kind of immediacy is needed for a robust redistributive institutional design at the global level.
} 


\section{Volume: 11, Issue: 3, July-September 2021}

phenomenon only. And thus to respond any global call to protect the basic human rights of global poor the proposed design must have immediacy transcending the national borders. I will not say that the proposed design would be completely coercive in nature using _threat forces ${ }^{6}$ to restore peace and justice but will certainly be semi-coercive arrangement with strong administrative, legal and financial sanctions in the cases of corruption, not complying to the directed duty of justice, directly or indirectly violating the human right of global poor etc. 


\section{Volume: 11, Issue: 3, July-September 2021}

\section{REFERENCES}

Armstrong, Chris (2012), -Global Distributive Justice: An Introduction\|, Cambridge, UK: Cambridge University Press.

Beitz, Charles (1975), -Justice and International Relationsll, Philosophy \& Public Affairs, Vol. 4, No. 4, pp. 360-389, Blackwell Publishing.

(1979), -Political Theory and International Relations\|, New Jersey:

Princeton University Press.

(1983), -Cosmopolitan Ideals and national Sentimentl, The Journal of Philosophy, Vol. 80, No. 10, Part 1: Eightieth Annual Meeting of the American Philosophical Association, Eastern Division, pp. 591-600.

(2000), -Rawls's Law of Peoples\|, Ethics, Vol. 110, No., pp. 669-696, The University of Chicago Press.

(2005), -Cosmopolitanism and Global Justicell, The Journal of Ethics, Vol.

9, pp. 11-27.

Blake, Michael (2002), _Distributive Justice, State Coercion, and Autonomy,'Philosophy and Public Affairs, Vol. 30, No. 3, pp. 257-96.

Brock, Gillian (2005), -Egalitarianism, Ideals, and Cosmopolitan Justicell, The Philosophical Forum, Vol. XXXVI, No.1, pp. 1-30.

(2009), - Global Justice: A cosmopolitan Account\|, Oxford: Oxford University Press.

Brooks, Thom (2002), Cosmopolitanism and Distributing Responsibilities\|, CRISPP, Vol. 5, No.3, pp. 92-97

-(2007), -Punishing States That Cause Global Povertyll, William Mitchell Law Review, Vol.33, No.2, pp. 519-532, This paper was presented originally at a -Pogge and His Critics\| Conference at the University of Newcastle.

Buchanan, Allen and O. Keohane, Robert (2006), -The Legitimacy of Global Governance Institutionsl, Ethics and International Affairs, Vol. 43, pp. 405-437. 


\section{Volume: 11, Issue: 3, July-September 2021}

Butt, Daniel (2012), -Global Equality of Opportunity as an International Standard of Distributive Justicell in Franc J. Garcia \& John Linarelli (ed.), -Global Justice and International Economic Law: Opportunities and Prospects\|, Cambridge University Press.

Caney, Simon (2001), -International Distributive Justicell, Political Studies, vol. 49, pp. 974- 997.

(2003), -Global Poverty and Human Rights: The Case for Positive

Duties\| in Simon Caney, -Global Poverty, Human Rights and Obligations\|, UNESCO Poverty Project

Ethical and Human Rights Dimensions of Poverty: Towards a New Paradigm in the Fight Against Poverty.

(2005), -Justice Beyond Borders: A Global Political Theoryll, Oxford:

Oxford University Press,

(2006), -Cosmopolitan Justice and Institutional Design: An Egalitarian Liberal Conception of Global Governancell, Social theory and Practice, Vol.32, No.4, pp. 725-756.

Follesdal, Andreas (2011), -The Distributive Justice of Global Basic Structure: A Category Mistakel, Politics, Philosophy and Economics, vol. 10, No.1, pp.46-65.

Gilabert, Pablo (2005), -The Duty to Eradicate Global Poverty: Positive or Negative?॥, Ethical Theory and Moral Practice, Vol. 7(5), pp. 537-550.

(2011), -From Global Poverty to Global Equality: A Philosophical Exploration $\|$, New York: Oxford University Press,

Hayward, Tim (2006), -Global Justice and the Distribution of Natural Resources\|, Political Studies, Vol. 54, pp. 349-369.

Jones, Charles (1999), “Defending Cosmopolitanism”, Oxford: Oxford University Press. Moellendorf, Darrel (2002), -Cosmopolitan Justicell, Boulder, Colorado, Westview Press. (2009), -Global Inequality and Injusticell, Journal of International Development, Vol. 21, pp. 1125-1136, John Wiley \& Sons, Ltd. (2011), -Why Global Inequality Matters\|, Journal of Social

Philosophy, Vol. 42, No. 1, pp. 99-109. 


\section{Volume: 11, Issue: 3, July-September 2021}

Murphy, Liam B. (1999), -Institution and the Demands of Justicell, Philosophy \& Public Affairs, Vol. 27, No. 4, Princeton University Press.

Nagel, Thomas (2005), -The Problem of Global Justicell, Philosophy \& Public Affairs, Vol. 33, No. 2, pp. 113-146, Blackwell Publishing, Inc.

Olsen, Johan P. (1997), -Institutional Design in Democratic Contexts\|, The journal of Political Philosophy, Vol.5, No.3, pp. 203-229.

Pogge, Thomas (2001), -Eradicating Systemic Poverty: Brief for a Global Resources

Dividend,\| Journal of Human Development, Vol. 2, No. 1, pp. 59-77

(2005), World Poverty and Human Rights, Ethics \& International Affairs,

Vol. 19, no. 1, pp. 1-7

(2011), -Allowing the Poor to Share the Earth\|, Journal of Moral

Philosophy, Vol. 8, pp. 335-352.

Slaughter, Steven (2008), -Institutionalising Cosmopolitan Responsibilities to the Global Poor: Institutional Cosmopolitanism, Human Rights and the State, in Unknown (ed.), Oceanic Conference on International Studies, pp. 1-15.

Steiner, Hillel (2011), The Grand Fund: A Reply to Casal, Journal of Moral Philosophy, Vol 8, pp. 328-334. 